\title{
Theoretical and experimental analysis of multifunctional high performance cement mortar matrices reinforced with varying lengths of carbon fibers
}

\author{
R.A. Khushnood ${ }^{\mathrm{a}}$, S. Muhammad ${ }^{\mathrm{a}}$, S. Ahmad ${ }^{\mathrm{b}} \bowtie$, J.M. Tullianic, \\ M.U. Qamar ${ }^{\mathrm{d}}$, Q. Ullah ${ }^{\mathrm{a}}$, S.A. Khan ${ }^{\mathrm{e}}$, A. Maqsom \\ a. NUST Institute of Civil Engineering, National University of Sciences \& Technology, (Islamabad, Pakistan). \\ b. Department of Building and Architectural Engineering, Bahauddin Zakariya University, (Multan, Pakistan). \\ c. Department of Applied Science \& Technology, Politecnico di Torino, (Turin, Italy). \\ d. Department of Irrigation \& Drainage, Faculty of Agricultural Engineering \& Technology, \\ University of Agriculture (Faisalabad, Pakistan) \\ e. Abasyn University, Peshawar Campus, (Peshawar, Pakistan) \\ f. Comsats Institute of Information Technology, (Wah Cantt, Pakistan). \\ $\bowtie$ sajjadahmad@bzu.edu.pk
}

Received 25 September 2017

Accepted 19 April 2018

On line first 1 October 2018

\begin{abstract}
An effective scheme to formulate high performance and multifunctional cement based mortar composites reinforced with varying lengths of carbon fibers has been devised. The detailed investigations pertaining to the fracture response of composites in cracks initiation and progression phases, their conducting mechanism and volumetric stability were performed with varying loads of $6 \mathrm{~mm}$ and $12 \mathrm{~mm}$ long carbon fibers at two different w/c ratios i.e. 0.45 and 0.50 . The experiments concluded that an optimum addition of carbon fibers results in substantial improvement of fracture properties alongside significant reduction in electrical resistivity and total plastic shrinkage. The field emission scanning electron microscopy of the cryofractured specimen revealed crack arresting actions of uniformly distributed carbon fibers through successful crack bridging and branching phenomenon.
\end{abstract}

KEYWORDS: Fiber reinforcement; Mortar; Flexural strength; Compressive strength; Microcracking

Citation/Citar como: Khushnood, R.A.; Muhammad, S.; Ahmad, S.; Tulliani, J.M.; Qamar, M.U.; Ullah, Q.; Khan, S.A.; Maqson, A. (2018) Theoretical and experimental analysis of multifunctional high performance cement mortar matrices reinforced with varying lengths of carbon fibers. Mater. Construcc. 68 [332], e172 https://doi.org/10.3989/ mc.2018.09617

RESUMEN: Análisis teórico y experimental de matrices multifuncionales de mortero de cemento de alta resistencia reforzadas con fibras de carbono de distintas longitudes. Se describe un sistema eficaz para la elaboración de morteros de cemento compuestos de alta resistencia, multifuncionales y reforzados con fibras de carbono de $6 \mathrm{~mm}$ y de $12 \mathrm{~mm}$ de longitud. Con este trabajo pormenorizado se pretende determinar, en morteros reforzados con fibras de carbono y con relaciones a/c de 0,45 y 0,50: i) la resistencia a la rotura bajo distintas cargas en las fases de iniciación y propagación de fisuras; ii) el mecanismo responsable del agrietamiento; y iii) la estabilidad volumétrica. Los resultados experimentales demuestran que la incorporación de una proporción óptima de fibras de carbono conlleva una mejora considerable de la resistencia a la rotura, además de una importante reducción tanto de la resistividad eléctrica como de la retracción plástica total. El análisis por microscopía electrónica de barrido de emisión de campo de las probetas criofracturadas puso de manifiesto la capacidad de las fibras de carbono, homogéneamente distribuidas, de detener el agrietamiento mediante el puenteado de las fisuras y el proceso de la ramificación.

PALABRAS CLAVE: Refuerzo de fibras; Mortero; Resistencia a la flexión; Resistencia a la Compresión; Microfisuración

ORCID ID: R.A. Khushnood (http://orcid.org/0000-0002-9532-4096); S. Muhammad (https://orcid.org/0000-00032180-1723); S. Ahmad (http://orcid.org/0000-0002-1139-8726); J.M. Tulliani (http://orcid.org/0000-0003-2419-4383); M.U. Qamar (http://orcid.org/0000-0003-3341-2581); Q. Ullah (https://orcid.org/0000-0002-4602-5428); S.A. Khan (http://orcid.org/0000-0003-4293-5907); A. Maqsom (http://orcid.org/0000-0002-3745-516X)

Copyright: (C) 2018 CSIC. This is an open-access article distributed under the terms of the Creative Commons Attribution 4.0 International (CC BY 4.0) License 


\section{INTRODUCTION}

Fiber reinforced cementitious composites (FRCCs) are gaining importance for their superior mechanical, electrical and chemical properties. Although the history of fibers utilization in composites dates back to $1500 \mathrm{BC}$ but in recent years many new types of synthetic fibers have been developed and being utilized along with natural fibers such as polypropylene (PP), polyvinyl alcohol (PVA), steel, glass, carbon fibers (CFs) and carbon nanotubes (CNTs) (1-10). Among synthetic fibers, CFs possess exceptional physical and mechanical characteristics; therefore, they are being used as reinforcement to augment the mechanical properties (i.e. strength and ductility) of composites (11-17). Beside strength and ductility, the fibers also improve the durability characteristics of the cementitious composites by refining their microstructure and restricting the development of induced micro cracks due to shrinkage and other chemical/physical phenomenon (18-23). The mechanical and fracture behavior of FRCCs depend upon several factors such as fiber's volume, length, diameter, their dispersion and bonding with the host matrix. CFs of smaller lengths are easy to disperse as compared to the longer or continuous ones; but their alignment is of paramount importance in the attainment of high strength i.e. Hambach et al. reported an increase of 13.4 times in the flexural strength of cement composites by incorporating highly aligned CFs prepared by nozzle injection technique (24). The CFs in the cement composites improve their peak strength as well as the pre and post peak energy absorption capacities $(25,26)$. The increase in fracture energy and tensile strength of fiber reinforced cementitious matrix depends upon the content and aspect ratios of added fibers (27). Composites reinforced with longer fibers exhibit improved mechanical performance in terms of tensile strength with substantial decrease in the workability whereas, shorter fibers produce relatively lesser improvement in mechanical characteristics.

In cementitious composites, the unstable crack propagation starts with the development of first crack in the matrix whereas, in fiber reinforced cementitious composites the crack propagation is restricted by the fibers which act as bridge within the cracked portions of the matrix. Fibers bridging controls and hinders the unstable growth of the cracks thus imparting toughness and energy absorption capability to the cementitious composites $(28,29)$. CFs not only possess exceptional mechanical properties but also exhibit high electrical conductivity, therefore their inclusion in cement matrices induce multifunctional characteristics (i.e. high fracture energy, toughness, strength and electrical sensitivity) in the resulting composites. Several researchers have reported appreciable increase in the mechanical performance of cementitious composites by incorporating fibers of various characteristics in terms of their type, shape, length, inclusion content etc. $(30-45)$. However, the literature is deficient in clearly discussing the relationship between $\mathrm{CFs}$ aspect ratios and the fracture performance of cement composites in conjunction with their electrical properties. Therefore, by considering the strong influence of length to diameter ratios of CFs on the mechanical and electrical performance of cementitious composites it is considered imperative to carry out an in-depth investigation on these parameters. To achieve this, in the present research, the CFs having two different aspect ratios were incorporated in the cementitious mortar composites with w/c of 0.45 and 0.50 and detailed investigations were carried out to analyze the mechanical strength, crack propagation, fracture energy, fracture toughness, electrical response, volumetric stability and micro structural characteristics of the modified multifunctional cementitious matrices. Furthermore, the critical pullout length and percolation threshold of carbon fibers were evaluated using different theoretical approaches and then the analytical values were used to compare and validate the experimental results.

\section{MATERIALS AND METHODS}

\subsection{Materials}

In the present research work, Grade-53 ASTM Type-1 (46), ordinary Portland cement (OPC), commercially available under the brand name of "Bestway" confirming to ASTM C150 specifications was utilized. The chemical and physical characteristics of OPC are presented in Table 1. The wellgraded siliceous sand with fineness modulus of 2.59 was used as fine aggregate. The polyacrylonitrile based CFs were acquired from Beijing Great Wall Co. Ltd. and used without any surface treatment. The detailed characteristics of $\mathrm{CFs}$ are reported in Table 2. Chemical grade Propane-1,2,3-triol (liquid glycerin) obtained from Sigma-Aldrich was used as a dispersant to prepare a homogenized suspension of carbon fibers before mixing them into the cement.

\subsection{Dispersion of carbon fibers}

The uniform dispersion of fibers in any fiberreinforced matrix is crucial for achieving optimum performance. In cementitious composites, it is usually difficult to ensure thorough dispersion of fibers in the cement matrix. Therefore, special attention was paid to achieve excellent dispersion of CFs in water prior to their addition into the cement. Initially, the water was mixed with $\mathrm{CFs}$ and sonicated for $10 \mathrm{~min}$ via high-energy sonication probe (UP50H, operated at 90\% amplitude). Then, $2.7 \%$ Propane-1,2,3-triol by weight of water was added in 
Theoretical and experimental analysis of multifunctional high performance cement mortar matrices reinforced $\bullet 3$

TABLE 1. Chemical composition and physical properties of OPC

\begin{tabular}{lccccccc}
\hline Chemical composition & $\mathbf{C a O}$ & $\mathrm{SiO}_{2}$ & $\mathbf{A l}_{\mathbf{2}} \mathbf{O}_{3}$ & $\mathbf{F e}_{2} \mathbf{O}_{3}$ & $\mathbf{M g O}$ & $\mathbf{S O}_{3}$ & $\mathbf{M i n o r ~ c o n t e n t s * ~}^{*}$ \\
\hline Content (\% by mass of cement) & 61.70 & 21.00 & 5.04 & 3.24 & 2.56 & 1.51 & 4.95 \\
Physical property & $\begin{array}{c}\text { Insoluble } \\
\text { residue }\end{array}$ & $\begin{array}{c}\text { Specific } \\
\text { gravity }\end{array}$ & $\begin{array}{c}\text { Specific } \\
\text { surface area }\end{array}$ & $\begin{array}{c}\text { Particle size } \\
\left(\mathbf{d}_{\mathbf{5 0}}\right)\end{array}$ & $\begin{array}{c}\text { Loss on } \\
\text { ignition }\end{array}$ & \\
Content & $0.54 \%$ & 3.10 & $3.45 \mathrm{~m}^{2} / \mathrm{g}$ & $13.58 \mu \mathrm{m}$ & $1.83 \%$ & & \\
\hline
\end{tabular}

* Minor contents such as $\mathrm{Na}_{2} \mathrm{O}, \mathrm{K}_{2} \mathrm{O}, \mathrm{P}_{2} \mathrm{O}_{5}$ and $\mathrm{TiO}_{2}$ etc.

TABLE 2. Physical characteristics of carbon fibers

\begin{tabular}{lccccccc}
\hline Designation & Length $(\mathbf{m m})$ & Diameter $(\boldsymbol{\mu m})$ & Density $\left(\mathbf{k g} / \mathbf{m}^{3}\right)$ & Purity $(\%)$ & Aspect ratio & $\begin{array}{c}\text { Tensile modulus } \\
(\mathbf{G P a})\end{array}$ & $\begin{array}{c}\text { Tensile strength } \\
(\mathbf{M P a})\end{array}$ \\
\hline CF1 & 6.00 & 7.00 & 1.76 & $\geq 98$ & 857 & 230 & 3450 \\
CF2 & 12.00 & 7.00 & 1.76 & $\geq 98$ & 1714 & 230 & 3450 \\
\hline
\end{tabular}

to the suspension and again sonicated for $10 \mathrm{~min}$. The Propane-1,2,3-triol assisted chemically to prepare homogeneous suspension of CFs in water. The dispersion level of CFs in water was analyzed through optical microscope (Figure 1).

\subsection{Cementitious composite sample preparation}

In total, five categories of cementitious mortar composite samples were prepared for each carbon fiber type with varying loads (i.e. $0.00,0.05,0.10$, 0.15 and $0.20 \%$ by weight of cement) analyzed at 0.45 and $0.50 \mathrm{w} / \mathrm{c}$ ratio. The ratio of cement to sand was fixed at 1:1.3 for all the composite samples. The complete description of mortar composite samples is presented in Table 3 . For the preparation of composite samples, the measured amounts of cement and sand were added to the $9.0 \mathrm{~L}$ Hobart mixer and dry mixing was carried out for 2 min. After dry mixing, the required amount of water having thoroughly dispersed CFs was added and mixing was continued for 6 min at high shear rate. Then, the mixture was poured in to the stainless steel molds of $40 \times 40 \times 160 \mathrm{~mm}^{3}$ dimensions. The molds

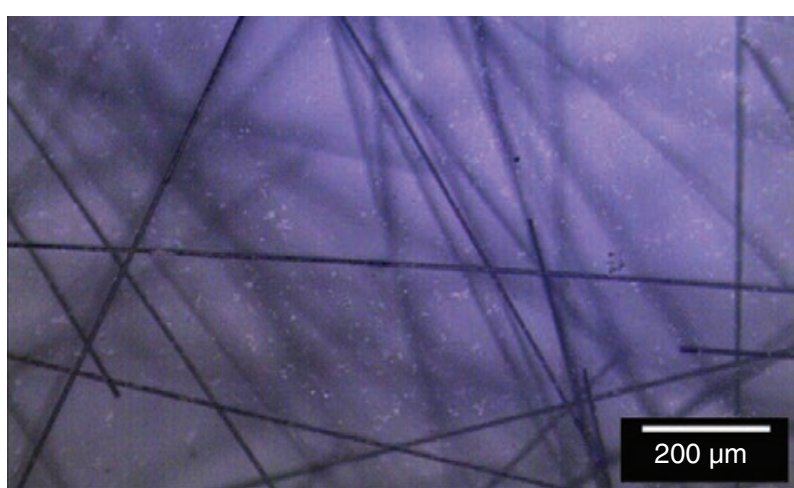

FIGURE 1. Optical microscopic image of dispersed $6 \mathrm{~mm}$ fibers $(\mathrm{CF} 1)$ in water were wrapped in plastic sheets and left at room temperature (i.e. $20.0^{\circ} \mathrm{C}$ and $95 \%$ relative humidity) for $24 \mathrm{~h}$. The dried samples were then removed from the molds and immersed in water and curing was carried out till the desired age of testing.

\subsection{Characterization of composite samples}

The cement mortar composite samples were analyzed for their flexural and compressive strengths by using universal testing machine (Pneumatic IPC Global UTM-25P) at 7, 14 and 28 days of curing.

TABLE 3. Composition of cementitious mortar formulations

\begin{tabular}{|c|c|c|c|}
\hline Notation & W/C ratio & $\begin{array}{c}\text { Carbon } \\
\text { Fiber Type }\end{array}$ & $\begin{array}{l}\text { Carbon Fiber } \\
\text { Content (\%) }\end{array}$ \\
\hline $45 \mathrm{M}$ & 0.45 & - & 0 \\
\hline 45MCF105 & 0.45 & $\mathrm{CF} 1$ & 0.05 \\
\hline 45MCF110 & 0.45 & $\mathrm{CF} 1$ & 0.10 \\
\hline 45MCF115 & 0.45 & $\mathrm{CF} 1$ & 0.15 \\
\hline $45 \mathrm{MCF} 120$ & 0.45 & $\mathrm{CF} 1$ & 0.20 \\
\hline 45MCF205 & 0.45 & $\mathrm{CF} 2$ & 0.05 \\
\hline $45 \mathrm{MCF} 210$ & 0.45 & $\mathrm{CF} 2$ & 0.10 \\
\hline 45MCF215 & 0.45 & CF2 & 0.15 \\
\hline $45 \mathrm{MCF} 220$ & 0.45 & $\mathrm{CF} 2$ & 0.20 \\
\hline $50 \mathrm{M}$ & 0.50 & - & 0 \\
\hline 50MCF105 & 0.50 & $\mathrm{CF} 1$ & 0.05 \\
\hline $50 \mathrm{MCF} 110$ & 0.50 & $\mathrm{CF} 1$ & 0.10 \\
\hline 50MCF115 & 0.50 & CF1 & 0.15 \\
\hline $50 \mathrm{MCF} 120$ & 0.50 & $\mathrm{CF} 1$ & 0.20 \\
\hline 50MCF205 & 0.50 & $\mathrm{CF} 2$ & 0.05 \\
\hline 50MCF210 & 0.50 & $\mathrm{CF} 2$ & 0.10 \\
\hline 50MCF215 & 0.50 & $\mathrm{CF} 2$ & 0.15 \\
\hline 50MCF220 & 0.50 & $\mathrm{CF} 2$ & 0.20 \\
\hline
\end{tabular}

*For each mix $750 \mathrm{~g}$ cement, $975 \mathrm{~g}$ sand and 2.7\% Propane1,2,3-triol by weight of water was used. 
The prism samples were tested under three-point bending in displacement controlled mode with a displacement rate of $0.005 \mathrm{~mm} / \mathrm{min}$ as shown in Figure $2 \mathrm{a}$, while the two broken halves were analyzed for their compressive strength at a controlled rate of $1.2 \mathrm{~mm} / \mathrm{min}$. Electrical resistance values of the composite specimens were tested by using digital multi-meter (U1733C, Agilent Technologies, Inc., USA) having $0.20 \%$ of measuring accuracy via two electrode method (Figure 2b). For carrying out the electrical resistivity measurements, electrical

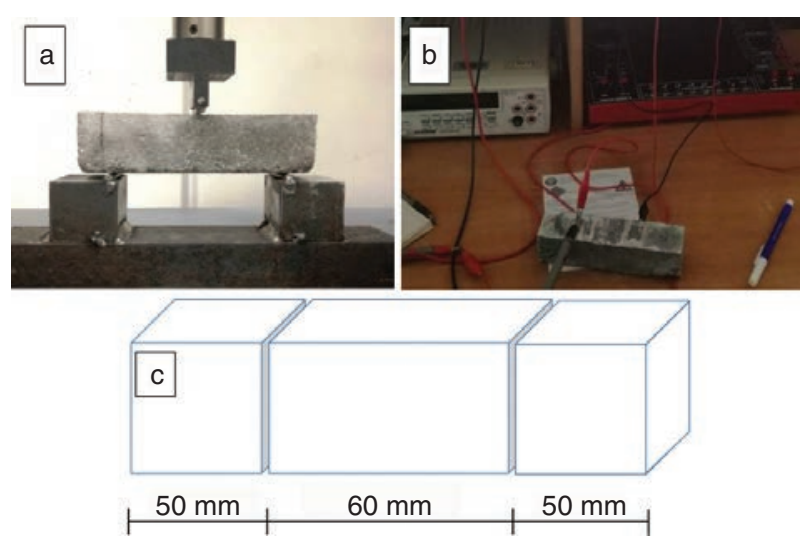

FiguRE 2. Experimental setup for three-point bending (a), electrical resistivity measurements (b) and electrical contact configuration (c) conducting paint was applied around the perimeter of the samples at specified planes (Figure 2c). The painted planes were wrapped with copper wires to ensure perfect contact between the sample and the electrodes. To study the influence of carbon fibers addition on the shrinkage behavior of mortar composites, the specimens were tested using shrinkage apparatus (Schwindrine, Germany) operated under linear protocol. Small chips of the broken samples were analyzed through scanning electron microscope (SEM) to observe the attained level of dispersion of $\mathrm{CFs}$, their morphology and interfacial interaction with the host cement matrix.

\section{RESULTS AND DISCUSSIONS}

\subsection{Dispersion of carbon fibers in cement composites}

The dispersion of CFs is very crucial and plays an important role in crack bridging and fracture energy enhancement of the composites. The dispersion was thoroughly analyzed by SEM analysis; typical micrographs showing the dispersion of CF1 and $\mathrm{CF} 2$ in cement mortar composites are presented in Figure 3. The observations indicate that the selected dispersant, dispersing scheme and mixing regime are very effective in achieving the thorough dispersion of $\mathrm{CFs}$ inside the host mortar matrix. In the cement mix, the surfactant reduces the surface tension thus effectively restricting the negative
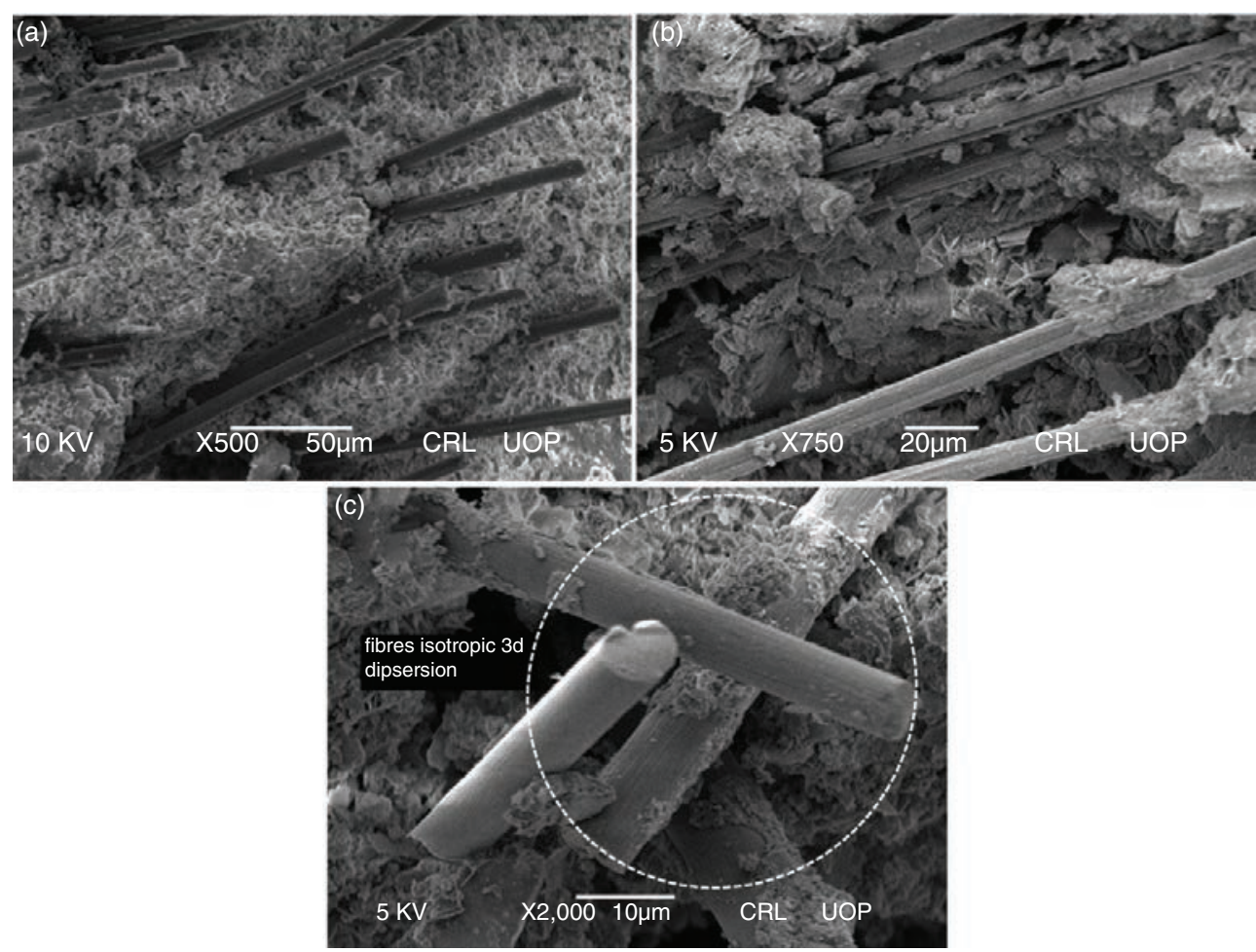

FIGURE 3. FESEM micrograph showing dispersion of CFs in cement matrix (a) CF1, and (b \& c) CF2 
capillary pressures. This effect results in availability of more free water for providing the workability and thorough dispersion of carbon fibers in the mix. Additionally, this also reduces the overall shrinkage of the cement paste as demonstrated by several researchers $(47,48)$.

\subsection{Flexural behavior of cement mortar composites}

The typical load vs displacement behavior of the cement mortar composites samples after 28 days of curing is presented in Figure 4. The flexural test results reveal that the addition of CFs not only enhances the peak stress but also increases the rupture strain.

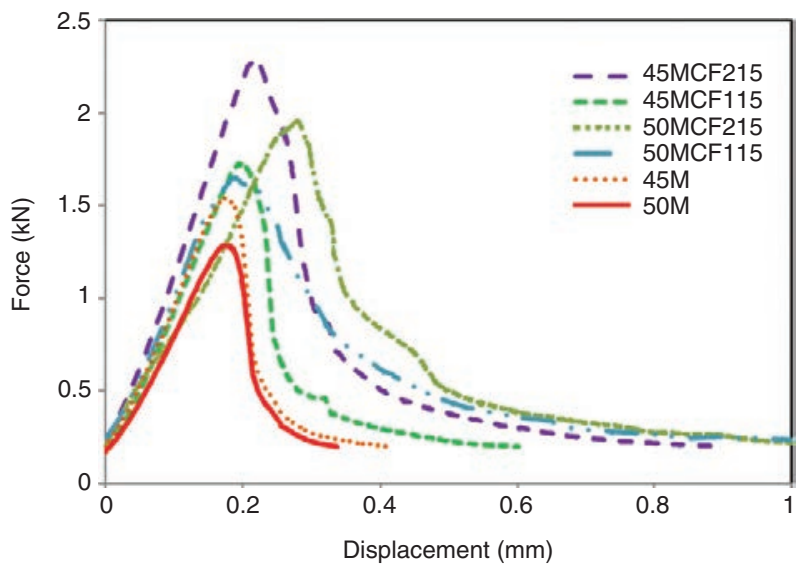

FIGURE 4. Typical force vs mid-point displacement curves for CFs modified cement mortar composites at 28 days
The addition of CF1 and CF2 by $0.15 \mathrm{wt}^{\mathrm{C}} \%$ at w/c of 0.45 exhibited $32 \%$ and $83 \%$ increase in modulus of rupture (MOR), respectively. The carbon fibers inclusion also increases the ductility factor $(\mu)$, which is defined as the difference between the ultimate displacement $\left(\delta_{\mathrm{u}}\right)$ and the displacement at yield $\left(\delta_{\mathrm{y}}\right)$. The influence of various amounts of carbon fibers on the ductility factor is presented in Figure 5. The MOR of cement mortar specimens was determined using eq. [1] under three-point bending test. Here, ' $\mathrm{P}$ ' is the maximum force in the load deflection curve, ' 1 ' is the span length, ' $w$ ' is the specimen width and ' $h$ ' is the specimen height [1] (49):

$$
\operatorname{MOR}=3 \mathrm{P} 1 / 2 w h^{2}
$$

The comparative analysis reveals that the MOR of cement mortar composites initially increases with the CFs additions up to $0.15 \mathrm{wt} \%$ and afterwards the trend begins to decline as reflected in Figure 6. The decrease in MOR with higher amount of CFs may be associated to the inter-fibers slippage and lesser effective dispersion due to the presence of relatively high number of fibers. The carbon fibers with higher aspect ratio performed better as compared to the shorter ones because the longer fibers possess more chance to bridge the growing crack in the composites due to their relatively longer lengths.

The failure deformation results indicate that the higher fiber content results in more capacity of cement mortar composites to undergo deformation before ultimate fracture. However, the total energy

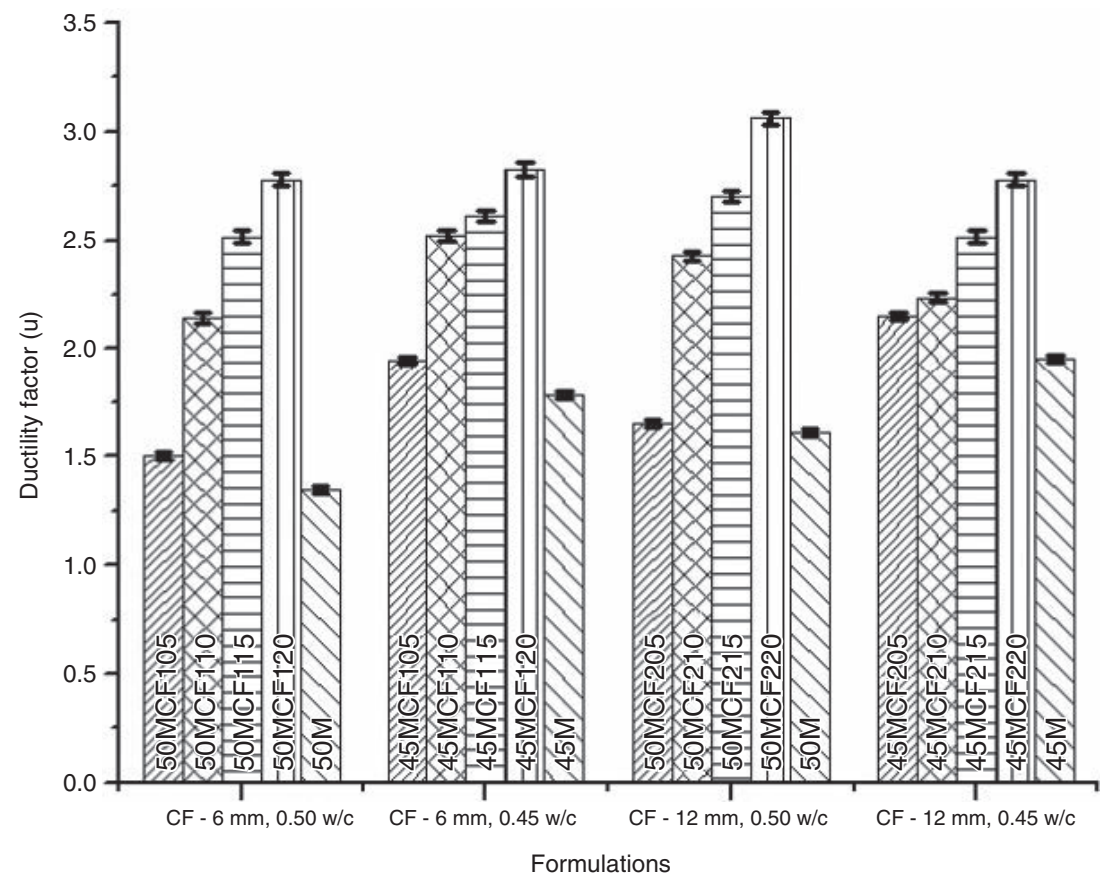

FIGURE 5. Ductility factor of the CFs modified cement mortar composites 


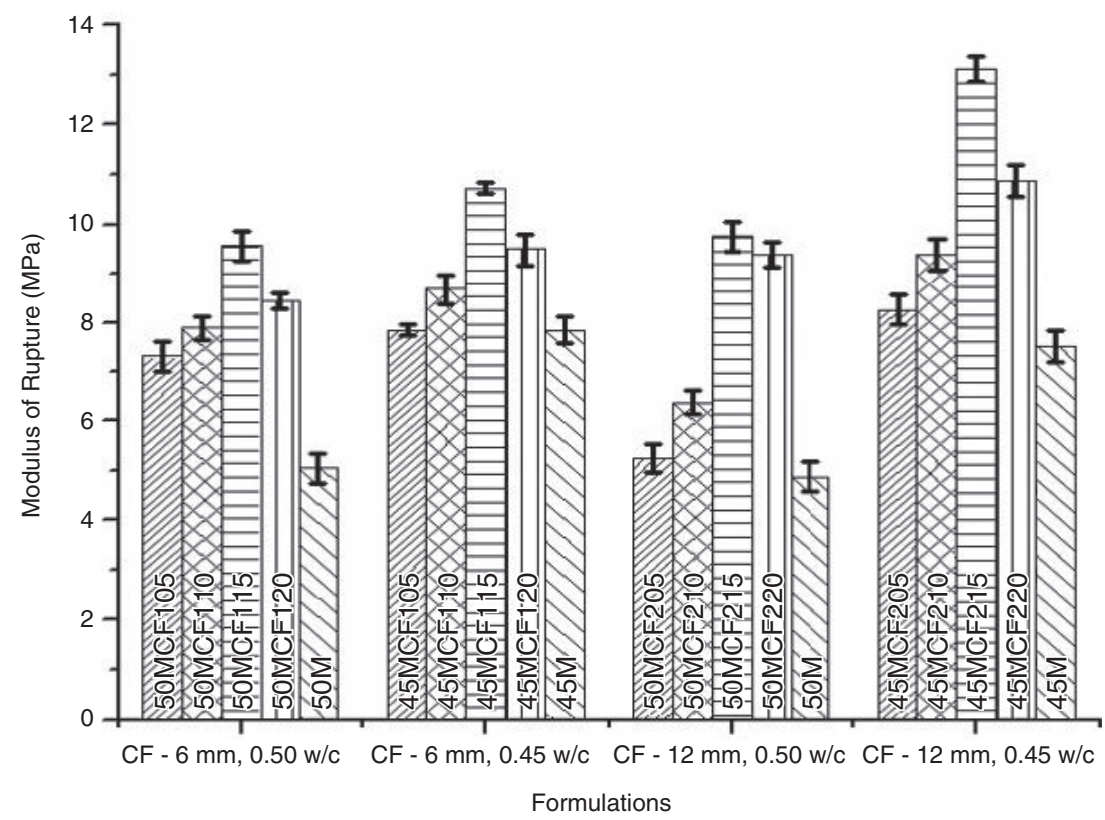

Figure 6. Modulus of rupture of the CFs modified cement mortar composites

absorption indicate that an optimum level of inclusion exists after which the performance of the resulting composites flattens as demonstrated through Figure 7. Hambach et al. (2016) reported the flexural strength enhancement of 5.5 and 14.3 times with the inclusion of perfectly aligned 1.0 and $3.0 \%$ carbon fibers in the cement paste (24), indicating that the flexural strength enhancement is not only the function of fibers content but also their orientation in the matrix $(50,51)$.
The absolute values of toughness (energy absorbed during fracture) depends entirely upon the specimen geometry and testing arrangements. Therefore, to enable realistic comparison of performance, ASTM C 1018 (52) suggests to evaluate $I_{5}, I_{10}$ and $I_{20}$, defined as the ratios of area under the load-CMOD curve up to the deflections of 3.0, 5.5 and 10.5 times the firstcrack deflection to the area up to first-crack, respectively $(53,54)$. The toughness indices $I_{5}, I_{10}$ and $I_{20}$ has been calculated indicating the post crack toughness

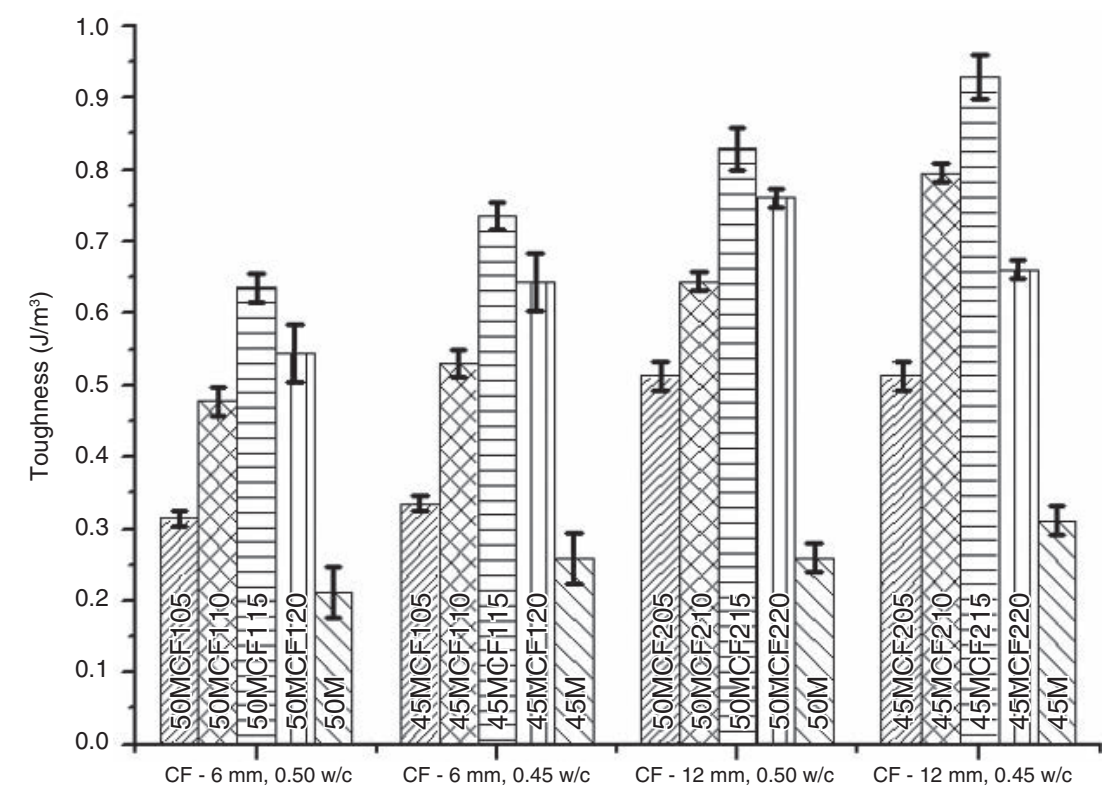

FIGURE 7. Ultimate toughness comparison of CFs modified cement mortar composites 
behavior of the carbon fiber reinforced prisms and presented in Figure 8.

Residual strength factors (RSFs), which are derived directly from toughness indices, characterize the level of strength retained after first crack simply by expressing the average post-crack load over a specific deflection interval as a percentage of first crack load (52). Trend attained against the varying lengths of reinforcing carbon fibers with the optimum additions is shown in the scatter given in Figure 9; mathematically RSFs are defined as follow [2] [3]:

$$
\begin{gathered}
\mathrm{R}_{(5,10)}=20 *\left(\mathrm{I}_{10}-\mathrm{I}_{5}\right) \\
\mathrm{R}_{(10,20)}=10 *\left(\mathrm{I}_{20}-\mathrm{I}_{10}\right)
\end{gathered}
$$

Based on above experimentally evaluated values, percentage increase in toughness indices and residual strength factors with $6 \mathrm{~mm}$ and $12 \mathrm{~mm}$ long CFs are summarized in Table 4.

\subsection{Behavior of cement mortar composites in compression}

The compressive strength test results indicate that the addition of CFs has slight influence on the compressive behavior of modified formulations as shown in Figure 10. The slight decrease at higher level of CFs additions may be attributed to the induced weakening effect of the entrained airvoids. In general, $\mathrm{CF} 1$ produced better compressive strength as compared to CF2. This effect may be attributed to the more efficient dispersion of short fibers in the matrix as compared to the relatively longer fibers. Figure 11 presents the comparison of compressive strength for $45 \mathrm{MCF} 15$ at 7,14 and 28 days. The reported increase seems to decline with the increasing age of cementitious mortar that might be associated to the much refined microstructure of the reference mix when reaching the characteristic age of 28 days.

\subsection{Electrical resistivity of carbon fiber reinforced cement mortar composites}

The electrical resistivity results of $\mathrm{CF} 1$ and $\mathrm{CF} 2$ filled cement mortar composites with w/c of 0.45 are reported in Figure 12. The electrical resistivity of cement mortar sharply decreases as the content

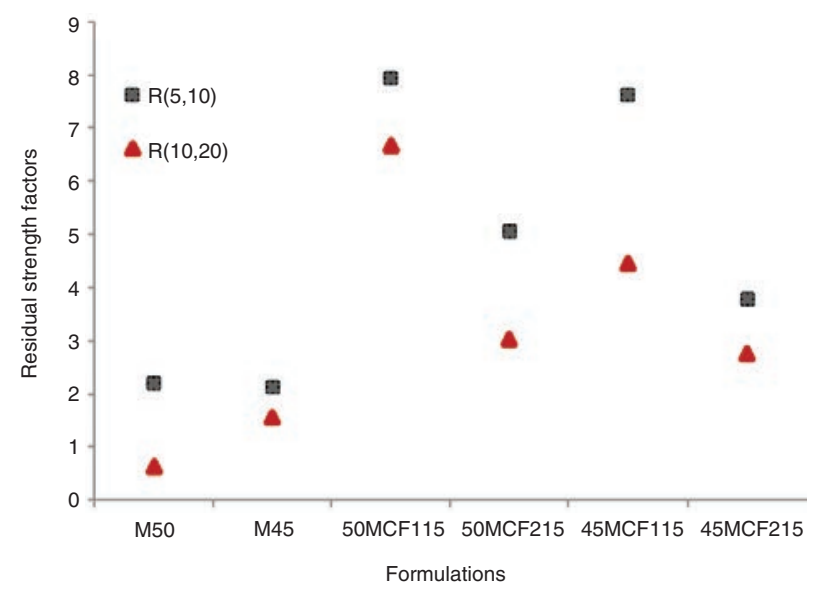

FIGURE 9. Residual strength factors of CFs modified cement mortar composites

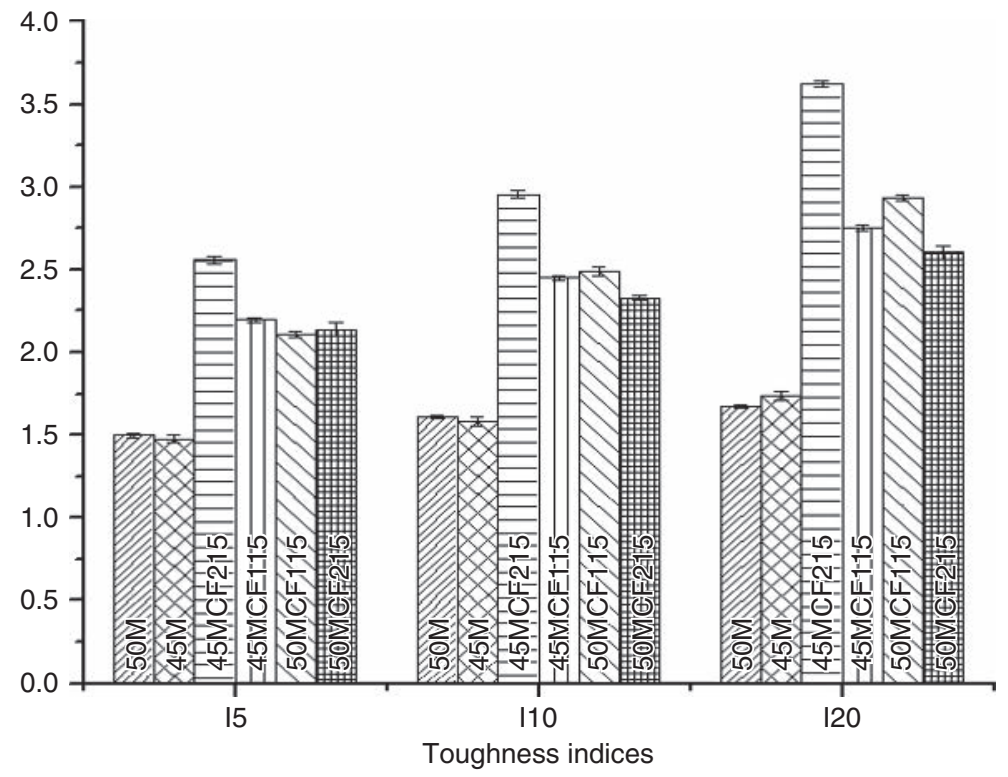

FIGURE 8. Comparison of the toughness indices of CFs modified cement mortar composites 
of conducting carbon fibers in the matrix increases $(55,56)$. An occurrence of enormous decrease in the value of resistivity at $0.15 \mathrm{wt} \%$ inclusion of $12 \mathrm{~mm}$ carbon fibers, is the sign of establishment of conducting mechanism inside the cementitious matrix due to the induced carbon fibers. An overall decrease in the electrical resistivity by $57.1 \%$ and $67.8 \%$, using $6 \mathrm{~mm}$ and $12 \mathrm{~mm}$ long carbon fibers evidences that the conductive mechanism of long fibers filled cement mortar is better than that of the shorter one.

\subsection{Volumetric stability}

Due to the reinforcing action, addition of CFs in the matrix tends to reduce the formation of cracks and thereby improve the shrinkage response of the

TABLE 4. The increased rate of toughness indices and residual strength factors

\begin{tabular}{lccccc}
\hline & \multicolumn{3}{c}{$\begin{array}{c}\text { \% increase in } \\
\text { toughness indices }\end{array}$} & \multicolumn{2}{c}{$\begin{array}{c}\text { \% increase in } \\
\text { residual strength }\end{array}$} \\
\cline { 2 - 6 } Samples & $\mathbf{I}_{\mathbf{5}}$ & $\mathbf{I}_{\mathbf{1 0}}$ & $\mathbf{I}_{\mathbf{2 0}}$ & $\mathbf{R}_{(\mathbf{5 , 1 0 )}}$ & $\mathbf{R}_{(\mathbf{1 0 , 2 0 )}}$ \\
\hline M50 & 100.0 & 100.0 & 100.0 & 100.0 & 100.0 \\
$\mathbf{5 0 M C F 1 1 5 ~}$ & 170.6 & 183.5 & 216.4 & 358.1 & 1059.6 \\
$\mathbf{5 0 M C F 2 1 5}$ & 146.5 & 152.1 & 164.4 & 228.9 & 379.5 \\
M45 & 100.0 & 100.0 & 100.0 & 100.0 & 100.0 \\
$\mathbf{4 5 M C F 1 1 5}$ & 142.8 & 157.3 & 168.9 & 358.2 & 287.2 \\
$\mathbf{4 5 M C F 2 1 5}$ & 144.8 & 147.0 & 149.7 & 178.0 & 177.4 \\
\hline
\end{tabular}

resultant formulations. In total, six formulations were selected to study the shrinkage response and their results are plotted in Figure 13. The results depicted significant reduction in the values of shrinkage with the proportionate increase in the content and the length of added carbon fibers. Maximum reduction of $307 \%$ as compared to the reference specimen was observed for $0.20 \mathrm{wt} \%$ addition of CF2 (Figure 14). Researchers have shown that free shrinkage and early age cracking of cementitious composites may be effectively controlled by using

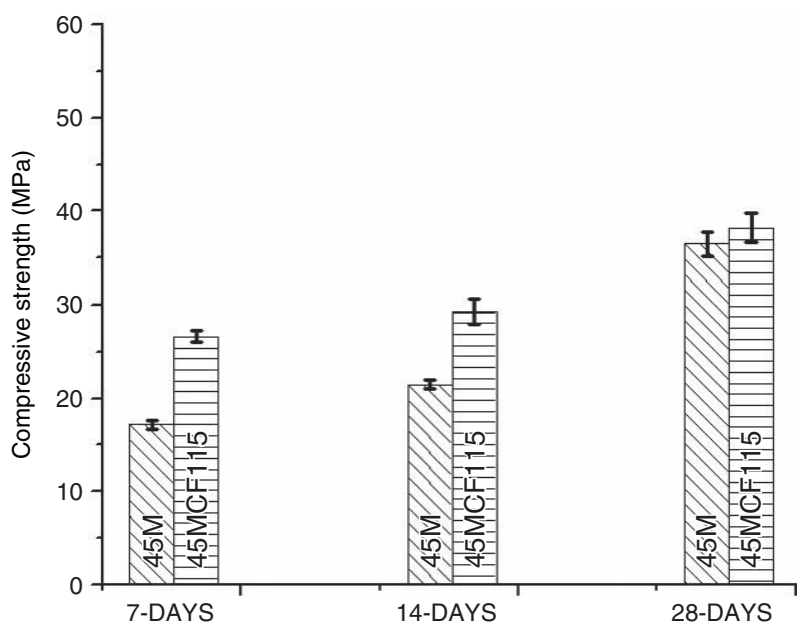

Figure 11. Comparison of effect of age for CFs modified mortar composites having optimum performance with the reference mix

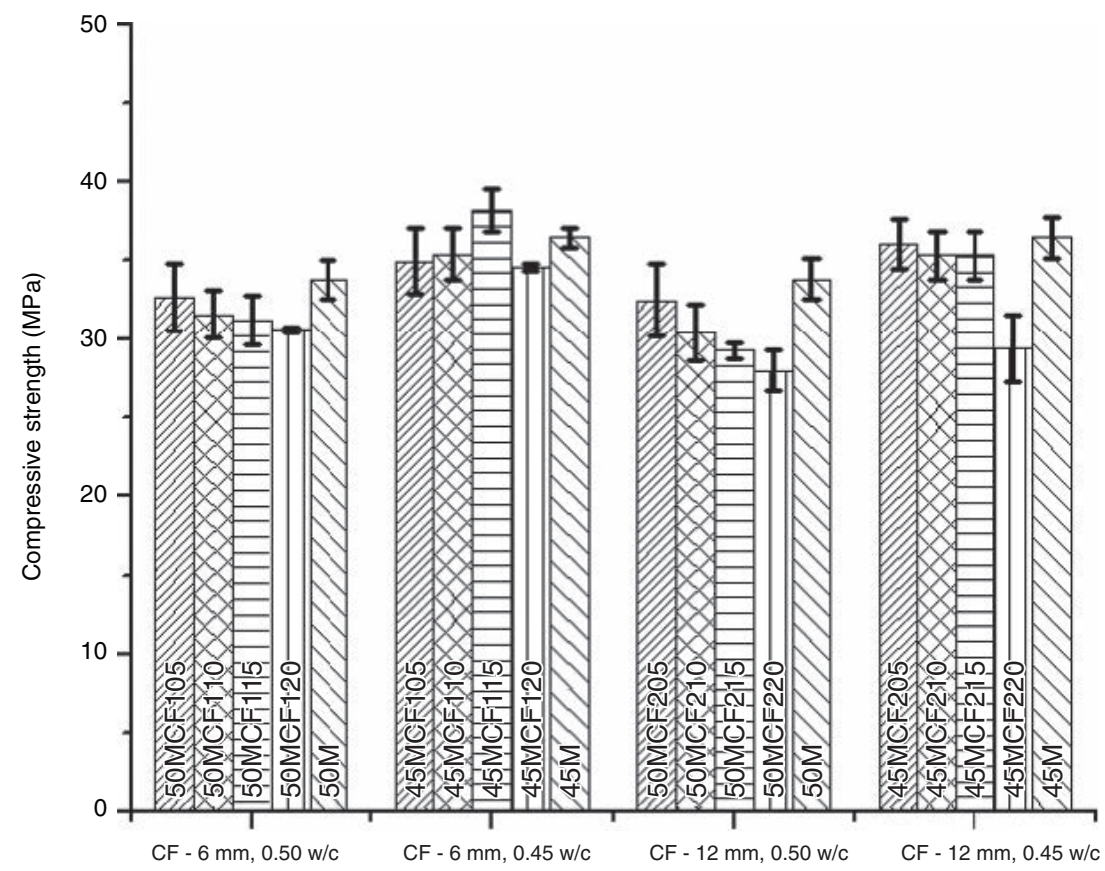

FIGURE 10. Comparison of characteristic compressive strength of CFs modified cement mortar composites at 28-days 


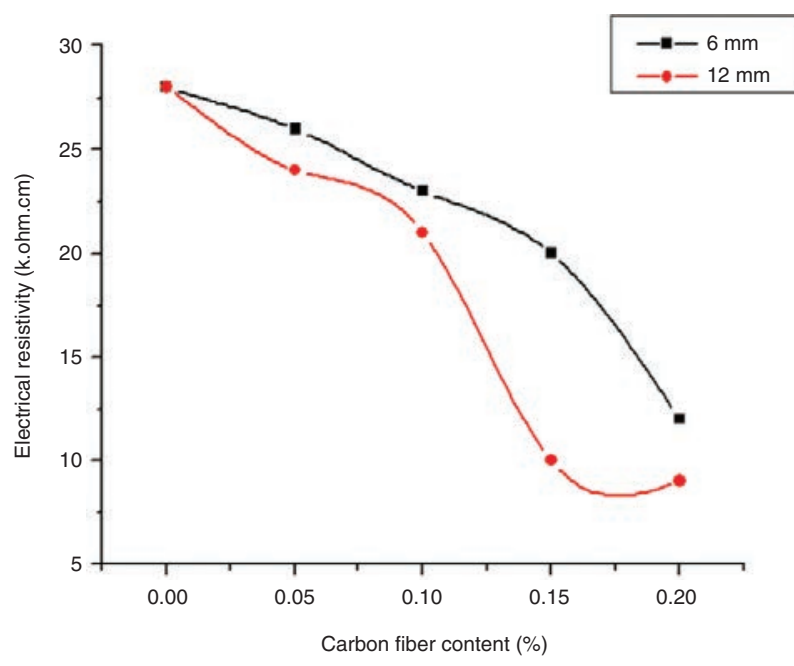

FIGURE 12. Comparison of the electrical resistivity of $6 \mathrm{~mm}$ and $12 \mathrm{~mm}$ carbon fiber filled cement mortar

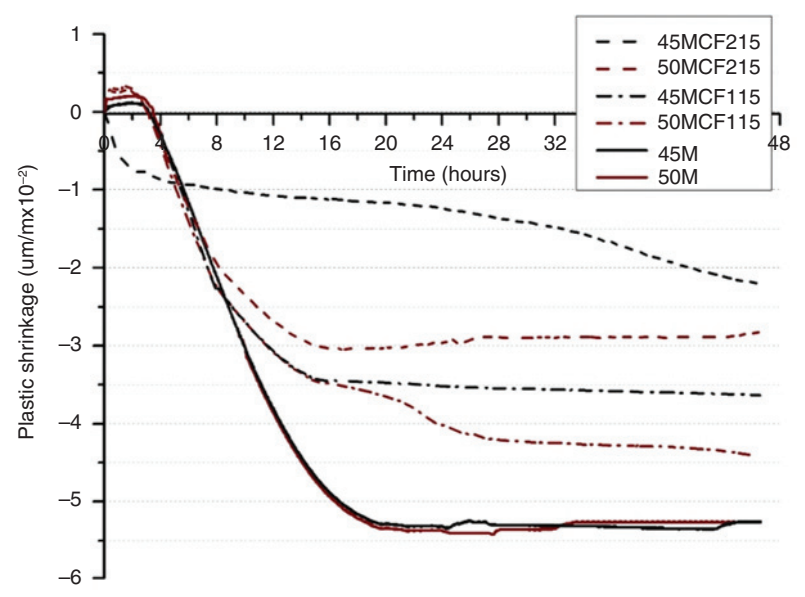

Figure 13. Comparison of the total linear shrinkage of $6 \mathrm{~mm}$ and $12 \mathrm{~mm}$ long carbon fiber filled cement mortar

propylene or sisal fibers possessing very low elastic modulus as compared to the carbon fibers $(57,58)$. This phenomenon is regarded to the low modulus of cement composite at early ages that is usually low as compared to the strength and elastic modulus of fibrous inclusions $(59,60)$.

\subsection{Microstructure}

The hardened cement mortar samples were observed under scanning electron microscope to further elaborate the strengthening mechanism of carbon fibers in the composites. The micrographs displayed evident signs of crack bridging and branching phenomenon along with fiber breakage and pullout at some occasional sites. The strength of interfacial bond between carbon fiber with cementitious matrix may be justified by the lightened groove marked on the matrix after the pull out of fiber under critical stress (Figure 15a).

\subsection{Theoretical calculations and analysis}

To understand the mechanics involved in the fracture behavior of carbon fiber reinforced cement mortar and to have the analytical validation of performed mechanical and electrical tests, some theoretical approaches were used in the form of mathematical equations. In the initial phase, numbers of carbon fibers were estimated according to eq. [5] that might be expected in unit volume of cementitious mortar as plotted in Figure 16. Then using the proposed equation by Romualdi et al. (61), the average center to center distance between the adjacent fibers was determined according to eq. [6], presented in Figure 17. In the end critical pullout length was evaluated by relating the tensile and flexural strength of reinforced cement based mortar composite as established by Hannanat et al (62). The calculated critical pullout length according to eq. [7] is presented in Figure 18. In the calculation procedure, the volume fraction of carbon fiber ' $\mathrm{V}_{\mathrm{f}}$ ' can be expressed as [4]:

$$
\mathrm{V}_{\mathrm{f}}=\mathrm{V} / \mathrm{V}_{\mathrm{fc}}=\mathrm{m} / \rho \cdot \mathrm{V}_{\mathrm{fc}}
$$

Here, ' $V$ ' is the total volume of carbon fiber in $\mathrm{mm}^{3}$, ' $\mathrm{Vfc}$ ' is the volume of carbon fiber filled cement mortar composite i.e. $40 \times 40 \times 160 \mathrm{~mm}^{3}$, ' $\rho$ ' is the density of carbon fiber i.e. $1800 \mathrm{~kg} / \mathrm{m}^{3}$ (as per manufacturer product data sheet) and ' $\mathrm{m}$ ' is the mass of carbon fiber. The number of carbon fibers ' $N$ ' enclosed in a cubic millimeter of carbon fiber filled cement based composite can be estimated by the following expression [5]:

$$
\mathrm{N}=\mathrm{V}_{\mathrm{f}} / \mathrm{A}_{\mathrm{f}} \mathrm{L}_{\mathrm{f}}=\mathrm{V}_{\mathrm{f}} / \pi\left(\mathrm{d}_{\mathrm{f}} / 2\right)^{2} \times \mathrm{L}_{\mathrm{f}}
$$

Here, ' $\mathrm{A}_{\mathrm{f}}$ ' is the cross-sectional area of carbon fiber in $\mathrm{mm}^{2}$, ' $\mathrm{L}_{\mathrm{f}}$ ' is the length of carbon fibers in $\mathrm{mm}$ and ' $\mathrm{d}_{\mathrm{f}}$ ' is the diameter of carbon fiber i.e. $7 \times 10^{-3} \mathrm{~mm}$. The average center-to-center spacing ' $\mathrm{s}$ ' can be expressed as [6]:

$$
\overline{\mathrm{s}}=13.8 \times \mathrm{d}_{\mathrm{f}} \times \sqrt{1 / \mathrm{V}_{\mathrm{f}}}=0.6557 \times \sqrt{1 / \mathrm{m}}
$$

Assuming carbon fiber is snapped at half of its length then critical pull out length ' $\mathrm{L}_{\mathrm{f}}^{\text {crit }}$ ' can be estimated using following equation [7]:

$$
\mathrm{L}_{\mathrm{f}}^{\text {crit }}=\mathrm{L}_{\mathrm{f}} \times \sqrt{\sigma_{\mathrm{f}}^{\mu} \eta_{\mathrm{o}} \mathrm{V}_{\mathrm{f}} / 2 \sigma_{\mathrm{fc}}^{\mu}}
$$




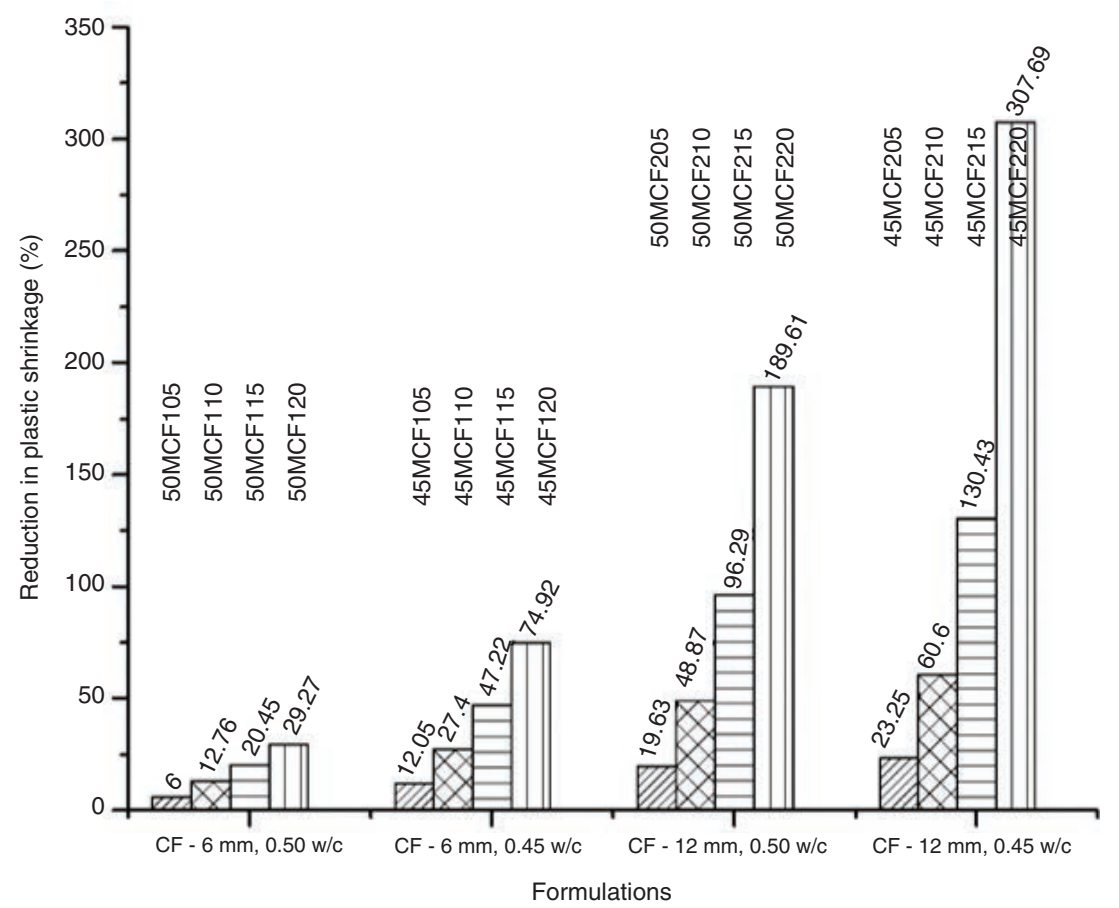

FIGURE 14. The decrease rate in the total linear shrinkage of carbon fiber filled cement mortar specimens
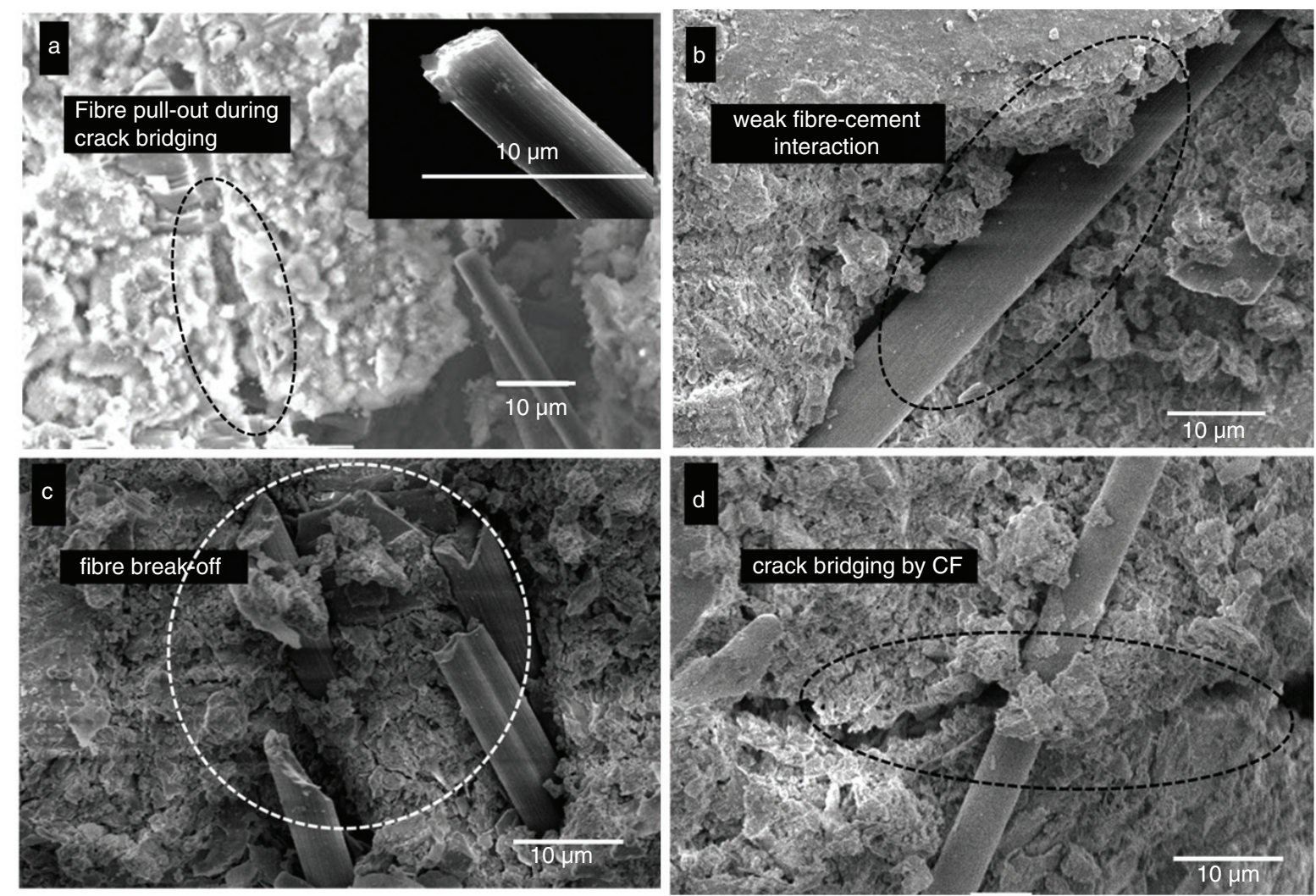

FIGURE 15. FESEM micrographs evidencing strengthening mechanism of cement mortar composite samples reinforced with CFs 


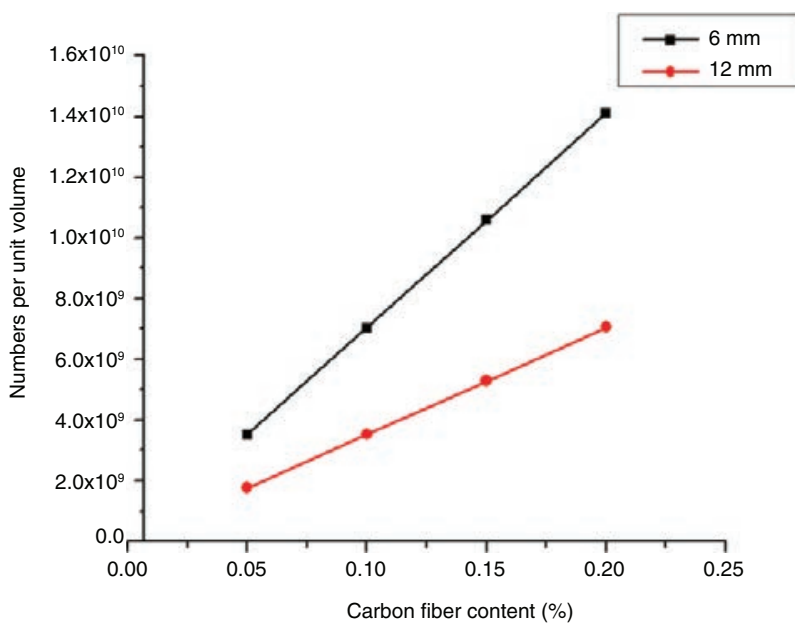

FIGURE 16. Estimation of the number of carbon fibers encapsulated inside the unit volume of carbon fiber filled cement mortar specimens (61)

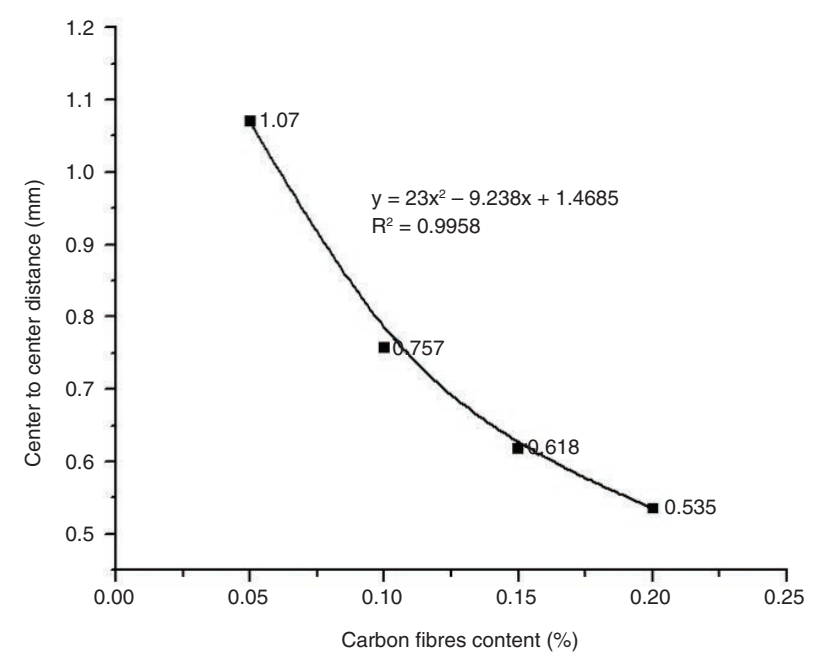

FIGURE 17. Average center-to-center spacing between two carbon fibers in carbon fiber filled cement mortar specimens calculated according to eq. [6] (62).

Here, ' $\sigma_{\mathrm{f}}^{\mu}$ ' is the tensile strength of carbon fibers i.e. $3450 \mathrm{MPa}$ (as per manufacturer product data sheet), ' $\eta_{\mathrm{o}}$ ' is the coefficient which depends upon the fibers orientation in the composite matrix and ' $\sigma_{\mathrm{fc}}^{\mu}$, is the tensile strength of carbon fibers filled cement mortar composite in MPa. The tensile strength of the composite ' $\sigma_{\mathrm{fc}}^{\mu}$ ' is associated with the flexural strength of the corresponding composite ' $\sigma_{\mathrm{fc}}^{\mathrm{b}}$ ' evaluated through experiments by using the mathematical relation given in eq. [8].

$$
\sigma_{\mathrm{fc}}^{\mu}=\sigma_{\mathrm{fc}}^{\mathrm{b}} / 2.44
$$

Here, ' $\sigma_{\mathrm{fc}}^{\mathrm{b}}$ ' is the 28 days flexural strength of carbon fiber filled cement mortar samples in MPa.

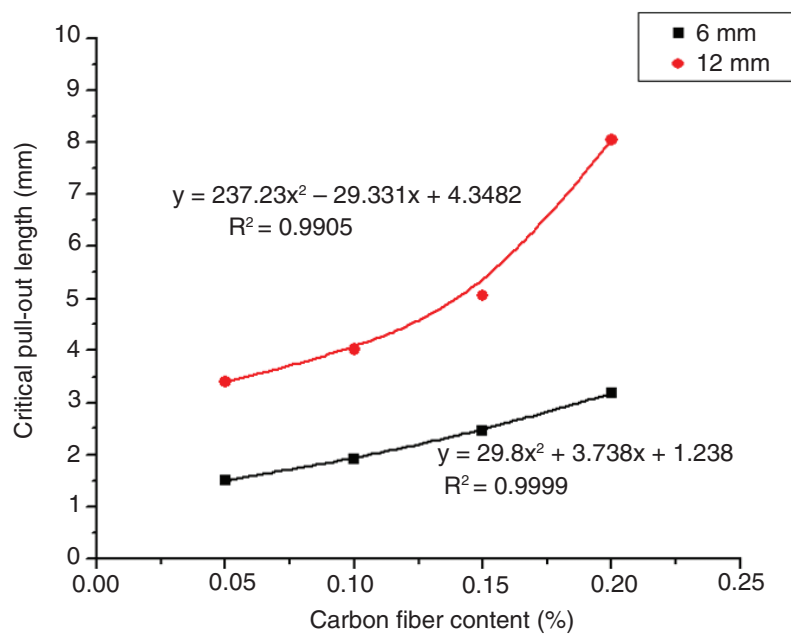

FIGURE 18. Estimated critical pullout lengths of $6 \mathrm{~mm}$ and $12 \mathrm{~mm}$ long carbon fibers calculated according to eq. [7].

TABLE 5. Theoretical percolations of $6 \mathrm{~mm}$ and $12 \mathrm{~mm}$ long carbon fibers

\begin{tabular}{lccc}
\hline \multirow{2}{*}{$\begin{array}{l}\text { Percolation threshold } \\
\text { (wrt wt\% of cement) }\end{array}$} & $\begin{array}{c}\text { IPD } \\
\text { approach }\end{array}$ & \multicolumn{2}{c}{ Celzard approach (64) } \\
\cline { 3 - 4 } & Lower limit & Upper limit \\
\hline $\begin{array}{l}\text { CF1-6 mm; } \\
\text { AR* }=857\end{array}$ & 0.0575 & 0.0029 & 0.0048 \\
CF2-12 mm; & 0.0281 & 0.0015 & 0.0028 \\
AR $^{*}=\mathbf{1 7 4 1}$ & & & \\
\hline
\end{tabular}

*AR (Aspect ratio)

For the conducting mechanism, Jing li et. al. (63) developed an improved analytical model based on IPD (Inter particle distance) to predict the percolation threshold ' $\mathrm{P}_{\mathrm{c}}$ ' $(\%)$ of graphite nano platelets with high aspect ratio in the polymer composites. His proposed equation [9] is as follows and the computed values for the present study are presented in Table 5:

$$
\operatorname{Pc}=27 \pi \mathrm{d}_{\mathrm{f}}^{2} \mathrm{~L}_{\mathrm{f}} / 4\left(\mathrm{~d}_{\mathrm{f}}+\mathrm{IPD}\right)^{3}
$$

According to quantum tunnelling mechanism electron hopping occurs when IPD is less than or equal to $10 \mathrm{~nm}$. Since IPD is very small in comparison with the average effective diameter ' $\mathrm{d}_{\mathrm{f}}$ ' of graphite nano platelets so it may be ignored and finally eq. [9] modifies in to eq. [10] given as:

$$
\begin{gathered}
\mathrm{Pc}=27 \pi \mathrm{L}_{\mathrm{f}} / 4 \mathrm{~d}_{\mathrm{f}} \\
\mathrm{Pc}=21.195 / \alpha \\
\alpha=\mathrm{d}_{\mathrm{f}} / \mathrm{L}_{\mathrm{f}}
\end{gathered}
$$


Celzard. et al. (64) proposed a relation between percolation threshold and aspect ratio of fillers based on the concepts of excluded volume; mentioned in eq. [13] (refer Table 5):

$$
\begin{aligned}
\operatorname{Pc}= & 1-\exp \left(-3.6 \mathrm{~d}_{\mathrm{f}} / \pi \mathrm{L}_{\mathrm{f}}\right) \leq \varnothing \mathrm{c} \\
& \leq 1-\exp \left(-5.6 \mathrm{~L}_{\mathrm{f}} / \pi \mathrm{d}_{\mathrm{f}}\right)
\end{aligned}
$$

\subsection{Comparison of analytical and experimental results}

The analytical results indicate that the number of carbon fibers in a unit volume increase linearly with the inclusion content but their center-to-center distance follows an exponential decremented pattern (Figure 16 and Figure 17 refers). The flattening pattern of center-to-center distance is more pronounced after $0.15 \mathrm{wt} \%$ inclusion of CFs. This phenomenon may be associated with the clumping and bundling of carbon fibers at higher concentrations (18). The clumping of fibers leads to heterogeneity inducing weak spots in the cementitious matrix. Therefore, an optimum enhancement in the fracture properties of the reinforced cement based mortar composite was observed with an addition by $0.15 \mathrm{wt} \%$ to cement.

The maximum length of carbon fiber to be pulled out from the matrix in damaged span defines the critical pull out length. The value of critical pullout length increases with proportionate increase in the content and length of carbon fiber. The $12 \mathrm{~mm}$ long, carbon fibers need more critical pullout length as compared to $6 \mathrm{~mm}$ long fibers for the same amount of inclusion (Figure 18 refers). The range of critical pullout length of carbon fibers inside cement mortar composites varies from $1.50 \mathrm{~mm}$ to $8.05 \mathrm{~mm}$. In the matrix, if the embedment length of a fiber is shorter than its critical pullout length then the fiber will be snapped out from the cement matrix during fracture, as observed in Figure 15. At higher concentrations, most fibers were observed to be pulled out while observing the microstructure of the tortured specimens. An increase in the critical value of pullout length and weak CFs-cement matrix interaction may clearly justify such failure mechanism. At smaller concentrations, fibers are more effectively bonded with the host matrix and thereby use much of their capacity in loads transmittance as evident through the lower number of pullout observed in SEM micrographs of chipped specimens.

The electrical resistivity values were found to decrease with the added content of conducting reinforcements in the form of carbon fibers. The major contributing parameters towards conductivity of the resultant cement mortar composites are carbon fibers and the electrolyte ions. With proportionate increase in the content of carbon fibers, their inter-fiber spacing begins to decline as shown in Figure 17. When the spacing reduces beyond certain limit that can entertain electrons from fiber to establish the tunnel effect, stable conductive mechanism is developed. It can be seen that the electrical resistivity decreases as the carbon fiber content increases until some optimum value after that the trend begins to flatten.

The percolations calculated via IPD (63) and Celzard (64) approaches were found to be underestimated on comparison with the values determined through experimentations. In fact, it is not possible to distribute and align all the fibers in their ideal 3 -d orientations therefore, it is almost impossible to imagine the same values of theoretical percolations through experiments. Additionally, there are a few fibers in the state of lapping which adds to the content of experimental percolations. At higher concentrations it is relatively tough to efficiently and isotropically disperse all the fibers and the level of complexity further increase while dealing with the relatively long fibers.

\section{CONCLUSIONS AND RECOMMENDATION}

In this study, $6 \mathrm{~mm}$ and $12 \mathrm{~mm}$ carbon fibers were investigated to formulate high performance and multifunctional cement based mortar composites at the selected water to cement ratio of 0.45 and 0.50. After in-depth analysis of theoretical and experimental results pertaining to the fracture behavior, electrical properties and the microstructure, following conclusions may be drawn:

1. The inclusion of well dispersed carbon fibers in the cement mortar matrix not only enhance the modulus of rupture but also substantially improve the toughness and post crack performance.

2. An enormous improvement of about three times in ultimate toughness is achieved with an optimum addition of 0.15 weight percent of $6 \mathrm{~mm}$ and $12 \mathrm{~mm}$ long carbon fibers. Beyond the optimum content the performance tends to decline that may be associated to the clumping and bundling of carbon fibers at higher concentrations.

3. The decrease in electrical resistivity is relatively more for mixes containing $12 \mathrm{~mm}$ long carbon fibers. The percolation threshold for $12 \mathrm{~mm}$ carbon fibers is found to be in between 0.10 to 0.15 percent weight contents. The main reason for the reduction of electrical resistivity is the tunnel effect and the lapping of carbon fiber. It is easy to establish the steadier conductive network for more and longer carbon fibers in the cement mortar.

4. The analytical results pertaining to the critical pullout length and percolation threshold using different theoretical approaches are well in 
agreement with the experimental findings. The theoretical percolations are bit conservative that might be linked with the complexity in attaining 3-d homogeneous and isotropic dispersion of carbon fibers inside cementitious matrix.

\section{Abbreviations}

$\begin{array}{ll}\text { AR } & \text { Aspect ratio } \\ \text { CFs } & \text { Carbon fibers } \\ \text { CNTs } & \text { Carbon nanotubes } \\ \text { FESEM } & \begin{array}{l}\text { Field emission scanning electron } \\ \text { microscopy }\end{array} \\ \text { FRCCs } & \text { Fiber reinforced cementitious composites } \\ \text { OPC } & \text { Ordinary Portland cement } \\ \text { PP } & \text { Polypropylene } \\ \text { PVA } & \text { Polyvinyl alcohol } \\ \text { RSFs } & \text { Residual strength factors } \\ \text { w/c } & \text { Water to cement ratio }\end{array}$

\section{ACKNOWLEDGEMENTS}

The authors are thankful to Mr. Muhammad Fawad (NICE, NUST), Ms. Sahab Farooq (IESE, NUST) and Mr. Muhammad Basharat (IESE, NUST) for providing valuable support in dealing with spectrophotometer, sonicator and FESEM. The authors also acknowledge the financial support from Higher Education Commission, Pakistan.

\section{REFERENCES}

1. Baeza, F.J.; Galao, O.; Zornoza, E.; Garcés, P. (2013) Effect of aspect ratio on strain sensing capacity of carbon fiber reinforced cement composites. Mater. Des. 51, 1085-94. https://doi.org/10.1016/j.matdes.2013.05.010.

2. Keleștemur, O.; Yildiz, S.; Gökçer, B.; Arici, E. (2014) Statistical analysis for freeze-thaw resistance of cement mortars containing marble dust and glass fiber. Mater. Des. 60, 548-55. https://doi.org/10.1016/j.matdes.2014. 04.013.

3. Beigi, M.H.; Berenjian, J.; Lotfi Omran, O.; Sadeghi Nik, A.; Nikbin, I.M. (2013) An experimental survey on combined effects of fibers and nanosilica on the mechanical, rheological, and durability properties of self-compacting concrete. Mater. Des. 50, 1019-29. https://doi.org/10.1016/j. matdes.2013.03.046.

4. Khushnood, R.A.; Ahmad, S.; Ferro, G.A.; Restuccia, L.; Tulliani, J.-M.; Jagdale, P. (2015) Modified fracture properties of cement composites with nano/micro carbonized bagasse fibers. Frat. ed Integrita Strutt. 34, 534 42. https:// doi.org/10.3221/IGF-ESIS.34.59.

5. Kordkheili, H.Y.; Hiziroglu, S.; Farsi, M. (2012) Some of the physical and mechanical properties of cement composites manufactured from carbon nanotubes and bagasse fiber. Mater. Des. 33, 395-8. https://doi.org/10.1016/j. matdes.2011.04.027.

6. Halvaei, M.; Jamshidi, M.; Latifi, M. (2014) Application of low modulus polymeric fibers in engineered cementitious composites. J. Ind. Text. 43[4], 511-24. https://doi. org/10.1177/1528083712465881.

7. Tiberti, G.; Minelli, F.; Plizzari, G. (2015) Cracking behavior in reinforced concrete members with steel fibers: A comprehensive experimental study. Cem. Concr. Res. 68, 24-34. https://doi.org/10.1016/j.cemconres.2014.10.011.

8. Aslani, F.; Bastami, M. (2015) Relationship between Deflection and Crack Mouth Opening Displacement of
Self-Compacting Concrete Beams with and without Fibers. Mech. Adv. Mater. Struct. 22[11], 956-67. https://doi.org/ 10.1080/15376494.2014.906689

9. Naeem, F.; Lee, H.K.; Kim, H.K.; Nam, I.W. (2017) Flexural stress and crack sensing capabilities of MWNT/ cement composites. Compos. Struct. 175, 86-100. https:// doi.org/10.1016/j.compstruct.2017.04.078.

10. Khitab, A.; Anwar, W.; Mansouri, I.; Tariq, M.K.; Mehmood, I. (2015) Future of civil engineering materials: A review from recent developments. Rev. Adv. Mater. Sci. $42[1], 20-7$.

11. Martone, A.; Faiella, G.; Antonucci, V.; Giordano, M.; Zarrelli, M. (2011) The effect of the aspect ratio of carbon nanotubes on their effective reinforcement modulus in an epoxy matrix. Compos. Sci. Technol. 71[8], 1117-23. https://doi.org/10.1016/j.compscitech.2011.04.002.

12. Metaxa, Z.; Konsta-Gdoutos, M.; Shah, S. (2010) Carbon Nanofiber-Reinforced Cement-Based Materials. Transp. Res. Rec. J. Transp. Res. Board. 2142[2142], 114-8. https:// doi.org/10.3141/2142-17.

13. Wen, S.; Chung, D.D.L. (2007) Partial replacement of carbon fiber by carbon black in multifunctional cementmatrix composites. Carbon N. Y. 45[3], 505-13. https://doi. org/10.1016/j.carbon.2006.10.024

14. Ozyurt, N.; Woo, L.Y.; Mason, T.O.; Shah, S.P.; Chung, D.D.L. (2006). Monitoring fiber dispersion in fiberreinforced cementitious materials: Comparison of AC-impedance spectroscopy and image analysis. ACI Mater. J. 103[5], 340-7. https://doi.org/10.14359/18156.

15. Sun, H.; Guo, G.; Memon, S.A.; Xu, W.; Zhang, Q.; Zhu, J.-H.; et al. (2015) Recycling of carbon fibers from carbon fiber reinforced polymer using electrochemical method. Compos. Part A Appl. Sci. Manuf. 78, 10-7. https://doi.org/ 10.1016/j.compositesa.2015.07.015.

16. Grunenfelder, L.K.; Suksangpanya, N.; Salinas, C.; Milliron, G.; Yaraghi, N.; Herrera, S.; et al. (2014) Bioinspired impact-resistant composites. Acta Biomater. 10[9], 3997-4008. https://doi.org/10.1016/j.actbio.2014.03.022.

17. Shahbazpanahi, S.; Abang Ali, A.A.; Kamgar, A.; Farzadnia, N. (2015) Fracture mechanic modeling of fiber reinforced polymer shear-strengthened reinforced concrete beam. Compos. Part B Eng. 68, 113-20. https://doi. org/10.1016/j.compositesb.2014.08.041.

18. Han, B.; Zhang, L.; Zhang, C.; Wang, Y.; Yu, X.; Ou, J. (2016) Reinforcement effect and mechanism of carbon fibers to mechanical and electrically conductive properties of cement-based materials. Constr. Build. Mater. 125, 479-89. https://doi.org/10.1016/j.conbuildmat.2016.08.063.

19. Mechtcherine, V. (2012) Towards a durability framework for structural elements and structures made of or strengthened with high-performance fibre-reinforced composites. Constr. Build. Mater. 31, 94-104. https://doi.org/10.1016/j. conbuildmat.2011.12.072

20. Rangelov, M.; Nassiri, S.; Haselbach, L.; Englund, K. (2016) Using carbon fiber composites for reinforcing pervious concrete. Constr. Build. Mater. 126, 875-85. https:// doi.org/10.1016/j.conbuildmat.2016.06.035.

21. Galao, O.; Bañón, L.; Baeza, F.; Carmona, J.; Garcés, P.; Baeza, J.F.; et al. (2016) Highly Conductive Carbon Fiber Reinforced Concrete for Icing Prevention and Curing. Materials (Basel). 9[4], 281. https://doi.org/10.3390/ ma9040281.

22. Boris, R.; Antonovič, V.; Kerienè, J.; Stonys, R. (2016) The effect of carbon fiber additive on early hydration of calcium aluminate cement. J. Therm. Anal. Calorim. 125[3], 1061-70. https://doi.org/10.1007/s10973-016-5312-2.

23. Li, Z. (2017) Predicting the drying shrinkage behavior of high strength portland cement mortar under the combined influence of fine aggregate and steel micro fiber. Mater. Construcción. 67[326], 119. https://doi.org/10.3989/ mc.2017.05916.

24. Hambach, M.; Möller, H.; Neumann, T.; Volkmer, D. (2016) Portland cement paste with aligned carbon fi bers exhibiting exceptionally high flexural strength (>100 MPa). Cem. Concr. Res. 89, 80-6. https://doi.org/10.1016/j.cemconres.2016.08.011 
25. Zhou, H.W.; Mishnaevsky, L.; Yi, H.Y.; Liu, Y.Q.; Hu, X.; Warrier, A.; et al. (2016) Carbon fiber/carbon nanotube reinforced hierarchical composites: Effect of CNT distribution on shearing strength. Compos. Part B Eng. 88, 201-11. https://doi.org/10.1016/j.compositesb.2015.10.035.

26. Khitab, A.; Ahmad, S.; Khushnood, R.A.; Rizwan, S.A.; Ferro, G.A.; Restuccia, L.; et al. (2017) Fracture toughness and failure mechanism of high performance concrete incorporating carbon nanotubes. Frat. ed Integrita Strutt. 11[42], 238-48. https://doi.org/10.3221/IGF-ESIS.42.26.

27. Mendes, T.M.; Hotza, D.; Repette, W.L.(2015) Nanoparticles in cement based materials: A review. Rev. Adv. Mater. Sci. 40[1], 89-96.

28. Ovid'ko, I.A.; Sheinerman, A.G. (2015) Toughening due to crack deflection in ceramic and metal graphene nanocomposites. Rev. Adv. Mater. Sci. 43[1-2], 52-60.

29. Ahmad, S.; Tulliani, J.-M.; Ferro, G.A.; Khushnood, R.A.; Restuccia, L.; Jagdale, P. (2015) Crack path and fracture surface modifications in cement composites. Frat. ed Integrita Strutt. 9[34], 524-33. https://doi.org/10.3221/ IGF-ESIS.34.58.

30. Passuello, A.; Moriconi, G.; Shah, S.P. (2009) Cracking behavior of concrete with shrinkage reducing admixtures and PVA fibers. Cem. Concr. Compos. 31[10], 699-704. https://doi.org/10.1016/j.cemconcomp.2009.08.004.

31. Graham, R.K.; Huang, B.; Shu, X.; Burdette, E.G. (2013) Laboratory evaluation of tensile strength and energy absorbing properties of cement mortar reinforced with micro- and meso-sized carbon fibers. Constr. Build. Mater. 44, 751-6. https://doi.org/10.1016/j.conbuildmat.2013.03.071.

32. Ferrari, V.J.; De Hanai, J.B.; De Souza, R.A. (2013) Flexural strengthening of reinforcement concrete beams using high performance fiber reinforcement cement-based composite (HPFRCC) and carbon fiber reinforced polymers (CFRP). Constr. Build. Mater. 48, 485-98. https://doi. org/10.1016/j.conbuildmat.2013.07.026.

33. Ferrara, L.; Park, Y.D.; Shah, S.P. (2007). Toughness properties and fiber dispersion in vibrated and self-consolidating fiber reinforced concrete. Proc 6th Int Conf Fract Mech Concr Concr Struct. p. 1341-9.

34. Metaxa,Z.S.; Seo, J.-W.T.; Konsta-Gdoutos, M.S.; Hersam, M.C.; Shah, S.P. (2012) Highly concentrated carbon nanotube admixture for nano-fiber reinforced cementitious materials. Cem. Concr. Compos. 34[5], 612-7. https://doi. org/10.1016/j.cemconcomp.2012.01.006.

35. Shu, X.; Graham, R.K.; Huang, B.; Burdette, E.G. (2015) Hybrid effects of carbon fibers on mechanical properties of Portland cement mortar. Mater. Des. 65, 1222-8. https:// doi.org/10.1016/j.matdes.2014.10.015

36. Ozyurt, N.; Mason, T.O.; Shah, S.P. (2007) Correlation of fiber dispersion, rheology and mechanical performance of FRCs. Cem. Concr. Compos. 29[2], 70-9. https://doi.org/ 10.1016/j.cemconcomp.2006.08.006.

37. Wu, Z.; Shi, C.; Khayat, K.H. (2016) Influence of silica fume content on microstructure development and bond to steel fiber in ultra-high strength cement-based materials (UHSC). Cem. Concr. Compos. 71, 97-109. https://doi. org/10.1016/j.cemconcomp.2016.05.005.

38. Kawashima, S.; Shah, S.P. (2011) Early-age autogenous and drying shrinkage behavior of cellulose fiber-reinforced cementitious materials. Cem. Concr. Compos. 33[2], 201-8. https://doi.org/10.1016/j.cemconcomp.2010.10.018.

39. Tran, T.K.; Kim, D.J.; Choi, E. (2014) Behavior of doubleedge-notched specimens made of high performance fiber reinforced cementitious composites subject to direct tensile loading with high strain rates. Cem. Concr. Res. 63, 54-66. https://doi.org/10.1016/j.cemconres.2014.05.003.

40. Nishiwaki, T.; Kwon, S.; Homma, D.; Yamada, M.; Mihashi, H. (2014) Self-healing capability of fiberreinforced cementitious composites for recovery of watertightness and mechanical properties. Materials (Basel). 7[3], 2141-54. https://doi.org/10.3390/ma7032141.

41. Jarabo, R.; Fuente, E.; Monte, M.C.; Savastano, H.; Mutjé, P.; Negro, C. (2012) Use of cellulose fibers from hemp core in fiber-cement production. Effect on flocculation, retention, drainage and product properties. Ind. Crops Prod. 39, 89-96. https://doi.org/10.1016/j.indcrop.2012.02.017.

42. Liu, X.; Yin, X.; Kong, L.; Li, Q.; Liu, Y.; Duan, W.; et al. (2013) Fabrication and electromagnetic interference shielding effectiveness of carbon nanotube reinforced carbon fiber / pyrolytic carbon composites. Carbon N. Y. 68, 501-10. https://doi.org/10.1016/j.carbon.2013.11.027.

43. Le, A.T.; Gacoin, A.; Li, A.; Mai, T.H.; Rebay, M.; Delmas, Y. (2014) Experimental investigation on the mechanical performance of starch-hemp composite materials. Constr. Build. Mater. 61, 106-13. https://doi.org/10.1016/j. conbuildmat.2014.01.084

44. Shah, D.U. (2014) Natural fibre composites: Comprehensive Ashby-type materials selection charts. Mater. Des. 62, 21-31. https://doi.org/10.1016/j.matdes.2014.05.002.

45. Fantilli, A P. Mihashi, H - Vallini, P (2007) Crack profile in $\mathrm{RC}, \mathrm{R} / \mathrm{FRCC}$ and $\mathrm{R} / \mathrm{HPFRCC}$ members in tension. Mater. Struct. 40[10], 1099-114. https://doi.org/10.1617/ s11527-006-9208-7.

46. ASTM. (2012). ASTM C150-12 Standard specification for Portland cement. https://doi.org/10.1520/C0150_ C0150M-12.

47. Magniont, C.; Escadeillas, G.; Oms-Multon, C.; De Caro, P. (2010) The benefits of incorporating glycerol carbonate into an innovative pozzolanic matrix. Cem. Concr. Res. 40[7], 1072-80. https://doi.org/10.1016/j.cemconres.2010. 03.009 .

48. Rongbing, B.; Jian, S. (2005) Synthesis and evaluation of shrinkage-reducing admixture for cementitious materials. Cem. Concr. Res. 35[3], 445-8. https://doi.org/10.1016/j. cemconres.2004.07.009.

49. Ferro, G.A.; Ahmad, S.; Khushnood, R.A.; Restuccia, L.; Tulliani, J.-M. (2014) Improvements in self-consolidating cementitious composites by using micro carbonized aggregates. Frat. ed Integrita Strutt. 30, 75-83. https://doi. org/10.3221/IGF-ESIS.30.11.

50. Musso, S.; Tulliani, J.-M.; Ferro, G.A.; Tagliaferro, A. (2009) Influence of carbon nanotubes structure on the mechanical behavior of cement composites. Compos. Sci. Technol. 69[11-12], 1985-90. https://doi.org/10.1016/j. compscitech.2009.05.002.

51. Arabi, N. (2018) Static and cyclic performance of cementitious composites reinforced with glass-fibres. Mater Construcción. 68[329], 146. https://doi.org/10.3989/mc. 2018.10216

52. ASTM. (1997). ASTM C 1018-97 Standard test method for flexural toughness and first-crack strength of fiberreinforced concrete. https://doi.org/10.1520/C1018-97.

53. Ali, M. (2016) Use of coconut fibre reinforced concrete and coconut-fibre ropes for seismic-resistant construction. Mater. Construcción. 66[321], e073. https://doi.org/10.3989/ mc.2016.01015

54. Ahmad, S.; Khushnood, R.A.; Jagdale, P.; Tulliani, J.-M.; Ferro, G.A. (2015) High performance self-consolidating cementitious composites by using micro carbonized bamboo particles. Mater. Des. 76, 223-9. https://doi.org/10.1016/j. matdes.2015.03.048.

55. Khushnood, R.A.; Ahmad, S.; Savi, P.; Tulliani, J.-M.; Giorcelli, M.; Ferro, G.A. (2015) Improvement in electromagnetic interference shielding effectiveness of cement composites using carbonaceous nano/micro inerts. Constr. Build. Mater. 85, 208-16. https://doi.org/10.1016/j. conbuildmat.2015.03.069.

56. Konsta-Gdoutos, M.S. Metaxa, Z.S - Shah, S.P (2010) Multi-scale mechanical and fracture characteristics and early-age strain capacity of high performance carbon nanotube/cement nanocomposites. Cem. Concr. Compos. 32[2], 110-5. https://doi.org/10.1016/j.cemconcomp.2009.10.007.

57. Sanjuán, M.A.; Tolêdo Filho, R.D. (1998) Effectiveness of crack control at early age on the corrosion of steel bars in low modulussisal and coconut fibre-reinforced mortars. Cem. Concr. Res. 28[4], 555-65. https://doi.org/10.1016/ S0008-8846(98)00003-9.

58. Sanjuán, M.A.; Moragues, A. (1994) A testing method for measuring plastic shrinkage in polypropylene fibre 
reinforced mortars. Mater. Lett. 21[3-4], 239-46. https:// doi.org/10.1016/0167-577X(94)90182-1.

59. Filho, R.D.T.; Sanjuán, M.A. (1999) Effect of low modulus sisal and polypropylene fibre on the free and restrained shrinkage of mortars at early age. Cem. Concr. Res. 29[10], 1597-604. https://doi.org/10.1016/S0008-8846(99)00136-2.

60. Sanjuán, M.A.; Moragues, A. (1997) Polypropylene-fibrereinforced mortar mixes: Optimization to control plastic shrinkage. Compos. Sci. Technol. 57[6], 655-60. https://doi. org/10.1016/S0266-3538(97)00012-2.

61. James P. Romualdi and James A. Mandel.; Romualdi, J.P.; Mandel, J.A.; James P. Romualdi and James A. Mandel. (1964). Tensile strength of concrete affected by uniformly distributed and closely spaced short lengths of wire reinforcement. J Proc. p. 657-72. https://doi.org/10.14359/7801.

62. Hannant, D.J. (1978) Fibre cements and fibre concrete. John Wiley Sons.

63. Li, J.; Kim, J.-K. (2007) Percolation threshold of conducting polymer composites containing 3D randomly distributed graphite nanoplatelets. Compos. Sci. Technol. 67[10], 2114-20. https://doi.org/10.1016/j.compscitech. 2006.11.010.

64. Celzard, A.; McRae, E.; Deleuze, C.; Dufort, M.; Furdin, G.; Marêché, J. (1996) Critical concentration in percolating systems containing a high-aspect-ratio filler. Phys. Rev. B. 53[10], 6209-14. https://doi.org/10.1103/PhysRevB.53.6209. 